Dirks, O. B. (1958). Int. dent. F., Lond., 8, г82.

Driak, F. (1956). Int. dent. F., Lond., 6, 537.

Dustin, J. P. (1958). Int. dent. F., Lond., 8, 186.

Hellman, M. (1925). Dent. Cosmos, 67, 185.

Humphreys, H. (1951). Brit. dent. F. 91, 216.

Keith, A. (1929). The Antiquity of Man, and ed. Vols, I and 2. London: Williams and Norgate.

McCown, T. D. \& Keith, A. (1939). The Stone Age of Mount Karmel. Oxford: Clarendon Press.

Macdonald, J. B. (1958). Int. dent. F., Lond., 8, I78.

Mummery, J. R. (1890a). Trans. odont. Soc., Lond., 2, 7.

Mummery, J. R. (1890b). Trans. odont. Soc., Lond., 2, 27.

Neumann, H. H. \& DiSalvo, N. A. (1957). Northw. Med., Seattle, p. 706.

Pedersen, P. O. (1952). Dent. Res. 72, s.70.

Ruffer, M. A. (r920). Amer. F. phys. Anthrop. 3, 335 .

Thielemann, K. (1958). Int. dent. F., Lond., 8, 342 .

\title{
The histochemistry of human tooth development
}

\section{By A. R. Ten Cate,* Department of Dental Anatomy and Dental Pathology, The \\ London Hospital Medical College, University of London}

Histochemical techniques are aimed at elucidating the chemistry of cells and tissues. Since it has been suggested (Landauer, 1954) that developmental defects are caused by an intervention in metabolic events at a cellular level, an understanding of the histochemistry of tooth development is of importance if the effects of nutritional disturbances on this process of development are to be understood.

The first signs of human tooth development occur 6 weeks after fertilization (I I mm crown-rump embryo), when an epithelial thickening arises in the region of the future dental arch. This is the forerunner of the ectodermal component of the teeth and is termed the dental lamina. The cells of the oral epithelium, from which the dental lamina arises, contain deposits of glycogen which serve as a store of energy.

Proliferation occurs at ten points in the dental lamina corresponding to the future position of the primary teeth; each resultant swelling is known as a tooth bud. As the tooth buds increase in size they proliferate into the underlying mesoderm and, by a process of differential growth, attain the cap stage of development, characterized by a shallow invagination on the deep surface of the bud (Pl. I $a$ ). As a result of the organizing influence of the epithelium, the mesoderm enclosed by the invaginated portion of the tooth bud proliferates and condenses to form the dental papilla, the formative organ of the dentine and the primordium of the pulp. The ectodermal portion of the tooth is known as the enamel organ. During the proliferative phase the glycogen content of the ectodermal cells diminishes. This diminution is due either to utilization of glycogen by anaerobic metabolism as proliferation proceeds or to the fact that, as cells penetrate deeper into the underlying mesoderm, they come into association with an improved vascular supply and the necessity for glycogen accumulation no longer exists.

\footnotetext{
* The histochemical findings on human tooth development presented in this paper form part of the work done for the fulfilment of the requirements for the Degree of Doctor of Philosophy of the University of London.
}

18 (1) 6 
With further development, the invagination on the deep surface of the bud deepens and its margins continue to grow down into the mesoderm until the tooth germ resembles a bell, the bell stage of development ( $\mathrm{Pl}$. $\mathrm{x} b$ ). Histodifferentiation of the enamel organ occurs and it is now possible to recognize cell types to which specific functions may be ascribed. The outer surface of the enamel organ consists of regular cuboidal cells and is known as the external enamel epithelium. The inner surface, the internal enamel epithelium, consists of a layer of short columnar cells with large nuclei which later become the enamel-forming cells, the ameloblasts. The cells in the central core of the enamel organ become separated from each other by an increase of intracellular fluid and form a reticulum of star-shaped cells, the stellate reticulum. A layer of squamous cells (two to three cells deep), the stratum intermedium, appears between the stellate reticulum and the internal enamel epithelium.

With histodifferentiation of the enamel organ completed, determination of crown pattern of the tooth occurs. Butler (1956) considered the mechanism of determination of crown pattern and postulated a specific role for the stellate reticulum, that of water imbibition. It has been shown (Ten Cate, $1957 b$ ) that the stellate reticulum is histochemically active. Intracellular alkaline-phosphatase activity and the presence of glycogen probably indicate the production, by the stellate cells, of the extracellular acid mucopolysaccharide demonstrated in the stellate reticulum, which probably bestows the property of water imbibition upon it and an integral part to play in determination of the crown pattern.

With the determination of crown pattern completed, the hard tissues of the tooth, dentine and enamel, are elaborated. During dentinogenesis the following sequence of histological changes is known to occur. The formative cells of the dentine, the odontoblasts, differentiate under the organizing influence of the ameloblasts from spindle-shaped mesenchymal cells of the dental pulp (von Brunn, I89I). At this stage, the ameloblasts have elongated and their nuclei have migrated to the nonformative ends of the cells, away from the dentine papilla, and the central bodies (de Renyi, 1933) and Golgi apparatus (Beams \& King, I933) have migrated to the formative ends. Histochemically the ameloblasts are characterized by a high glycogen content (Ten Cate, 1957a) (Pl. re). The basement membrane between the internal enamel epithelium and the dental papilla thickens, and from the cell-rich layer beneath the odontoblasts, the subodontoblastic layer, originate argyrophilic fibres, the fibres of von Korff, which lie between the odontoblasts and merge with the basement membrane. A spreading out of the ends of von Korff's fibres related to the basement membrane occurs and their staining characteristics change, indicating a conversion from pre-collagen to collagen. The dentine matrix consists of a cementing substance and fibres and, in this state, is termed pre-dentine. Calcification of matrix occurs in such a manner that while apposition of a current layer of pre-dentine is taking place the previous layer is undergoing calcification. As dentine deposition occurs the odontoblasts retreat, leaving behind an attenuated process, the odontoblast process, which becomes incorporated in the dentine. 
The exact functional role of the odontoblasts is not yet fully understood and it can even be argued that they play no part in the formation of the dentine matrix. The ground substance is derived from the metachromatic ground substance of the pulp (Bevelander \& Johnson, 1955; Fulmer, 1958). The origin of the fibrous element is more obscure. Weidenreich's concept of a dual origin of the fibres of dentine matrix has recently been revived by Symons (r956), who considers that the fibres of the first-formed dentine represent the von Korff fibres whereas the remaining fibres of the matrix are formed by a morphologically distinct cell, the radial cell. Watson $\&$ Avery (1954) also suggested a dual origin for the fibres of the dentine matrix, from the pulp and from the odontoblast process. Microincineration studies (Hampp, I940) suggest that the odontoblast is concerned with the transport of mineral salts required for calcification of the dentine matrix.

The odontoblasts exhibit a high nucleic-acid and carbohydrate content ( $\mathrm{Pl}$. Ic). The subodontoblastic layer is rich in alkaline-phosphatase activity (Pl. Id) and its cells possess considerable amounts of ribonucleic acid. The ground substance in this region is metachromatic, indicative of the presence of an acid mucopolysaccharide. Controversy exists as to whether the odontoblasts themselves contain alkaline-phosphatase activity. Odontoblastic phosphatase activity has been described in non-human material by several authors (Bevelander \& Johnson, r 946; Cederberg, 1951; Avery, 1954; Symons, 1954) but other workers have refuted it, attributing the presence of the enzyme to diffusion artifacts (Gomori, I943; Sasso \& Castro, 1957). In human material no enzyme activity was elicited within the odontoblast with the azo-dye technique; with the Gomori cobalt technique transverse sections containing odontoblasts alone showed a negative response (Ten Cate, I958).

Recent work (Bourne, 1956; Glasstone, r958) has suggested that Robison's (1923) view that alkaline phosphatase plays a part in the precipitation of mineral salts is not correct, but rather that the enzyme is concerned with the genesis of organic matrices, associated either with fibrillogenesis (Bourne, I943, I944; Gould \& Gold, 195I; Frieden \& Hisaw, r95 I, I953; Buck, I953) or synthesis of ground substance (Moog \& Wenger, 1952; Kroon, 1952). These two views are not mutually exclusive because acid mucopolysaccharide of the ground substance may be related to fibre formation by acting as a template for the protofibrils of collagen (Meyer, r947, I950) which are produced intracellularly (Porter, I95 I; Jackson, I956a,b) and passed through the cell wall to become orientated extracellularly.

The presence of ribonucleic acid in cells is taken to indicate protein metabolism (Jeener, 1947) and can, therefore, be associated with fibrillogenesis. The subodontoblastic layer, from which the fibres of von Korff arise, is an active site of fibrillogenesis, and the presence of ribonucleic acid and enzyme activity is indicative of this synthesis. That the odontoblasts are rich in ribonucleic acid and devoid of alkaline-phosphatase activity suggests that protein synthesis is occurring, as postulated by Watson \& Avery (1954), and that phosphatase activity is associated with mucopolysaccharide synthesis and only indirectly with fibrillogenesis.

Amelogenesis has received much attention and a diversity of opinions has been expressed. Similar histological observations have been interpreted in many different 
ways (Saunders, Nuckolls \& Frisbie, 1942; Orban, Sicher \& Weinmann, I943; Marsland, I95I, I952; Butcher, r955); it is, however, generally accepted that the process of amelogenesis occurs in two phases, formation of the enamel matrix and the secondary calcification of the enamel matrix or enamel maturation. Enamel formation does not commence until the first increments of dentine have been deposited. This dentine forms a barrier which deprives the ameloblasts of their pulpal nutritional source. To compensate, the external enamel epithelium approximates to the ameloblasts, and blood vessels appear along the outer surface of the epithelium.

The ameloblasts produce, at their formative ends, processes known as Tomes processes. The intracellular substance between the ameloblasts condenses to form the terminal bar apparatus which is said to give rise to the fibrous inter-rod substance of enamel (Orban, 1949). The Tomes process then undergoes further chemical changes and becomes the pre-enamel rod into which calcium salts are precipitated. This constitutes the formation of the enamel matrix. Enamel maturation occurs when all the enamel matrix has been elaborated and is characterized by the crystallization of mineral salts and the simultaneous disappearance of water and organic material so that the enamel reaches its final high inorganic content.

The enamel matrix consists of a fibrous component, probably akin to keratin, and a ground substance containing acid mucopolysaccharide, into which inorganic salts are deposited. Histochemical observations on amelogenesis are in accord with this view. The high glycogen content of the ameloblasts disappears as the Tomes process is elaborated (P1. I $e$ ) and it has been postulated (Ten Cate, 1957a) that this process represents the phosphorolytic degradation of glycogen to hexosephosphate esters utilized in the synthesis of acid mucopolysaccharide of the enamel matrix. The absence of glycogen from odontoblasts, cells with a similar function to perform, is explained by the proximity of a rich vascular supply (James, I955), hexosephosphate esters being derived directly from the blood.

The presence of alkaline phosphatase at sites of fibrillogenesis is well recognized, yet the ameloblasts show no phosphatase activity during enamel-matrix formation (Gomori, I943; Avery, 1954; Sasso \& Castro, I957; Ten Cate, I958) (P1. Id). The stratum intermedium, however, is rich in phosphatase activity ( $\mathrm{Pl} . \mathrm{I} d)$ and it is of significance that in both dentinogenesis and amelogenesis the formative cells are devoid of the enzyme, yet exist in close relationship with cell layers rich in the enzyme, the subodontoblastic layer and the stratum intermedium respectively. In accord with the view that alkaline-phosphatase activity at calcification sites is associated with the production of the organic matrix, it can be postulated that mucopolysaccharide is elaborated in the stratum intermedium and flows down the cell interfaces between the ameloblasts to the terminal bar region where it forms a template for the protofibrils produced by the ameloblasts rich in ribonucleic acid.

This interpretation of the histochemical findings on the human developing tooth is supported by recent work on amelogenesis in rodents investigated with the electron microscope. Fearnhead (1958) has shown that the cell wall of the ameloblast plays an important part in formation of enamel matrix. The fibrous protein of the 


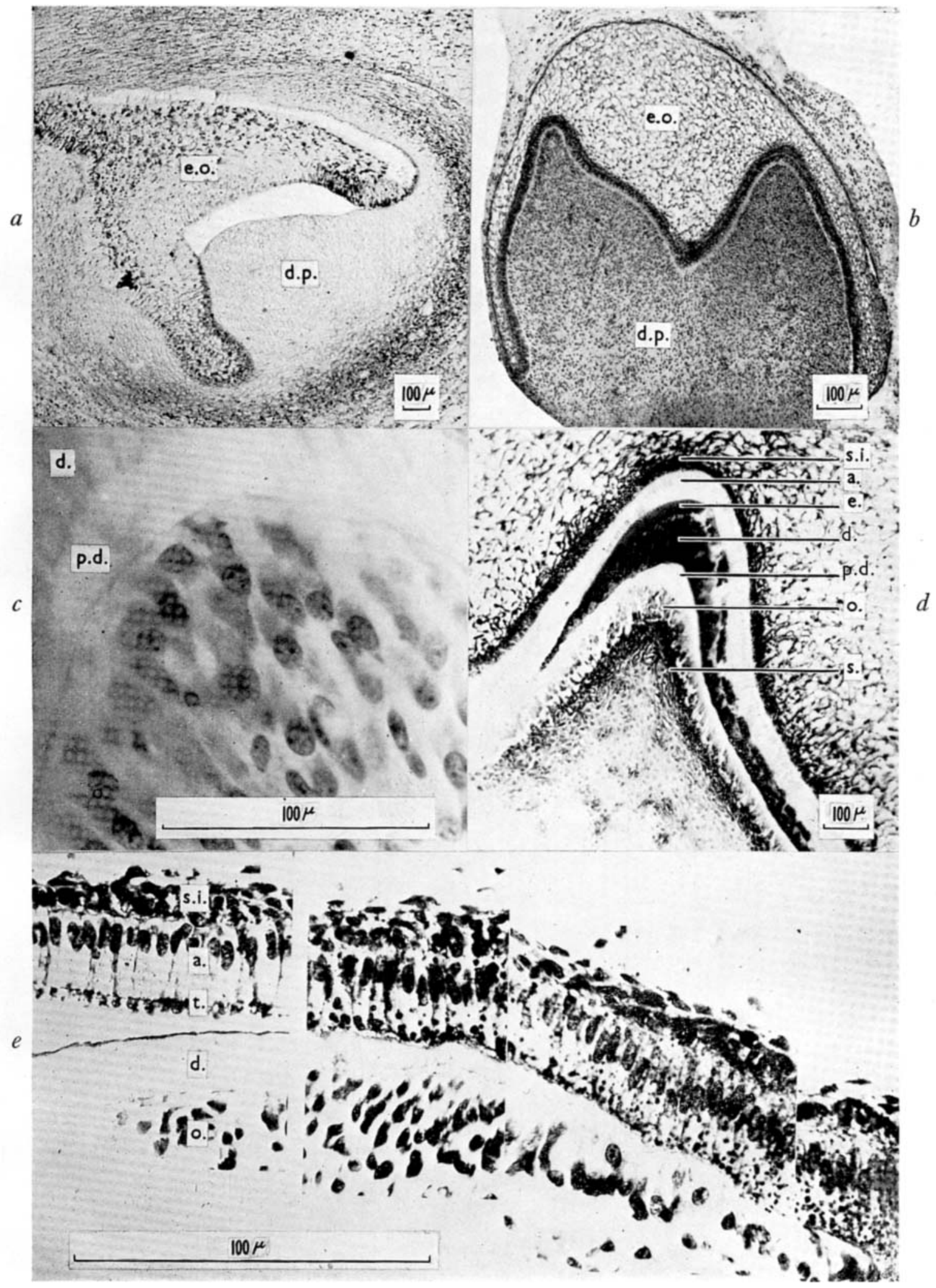

Proceedings of The Nutrition Society, Vol. I 8, No. I 


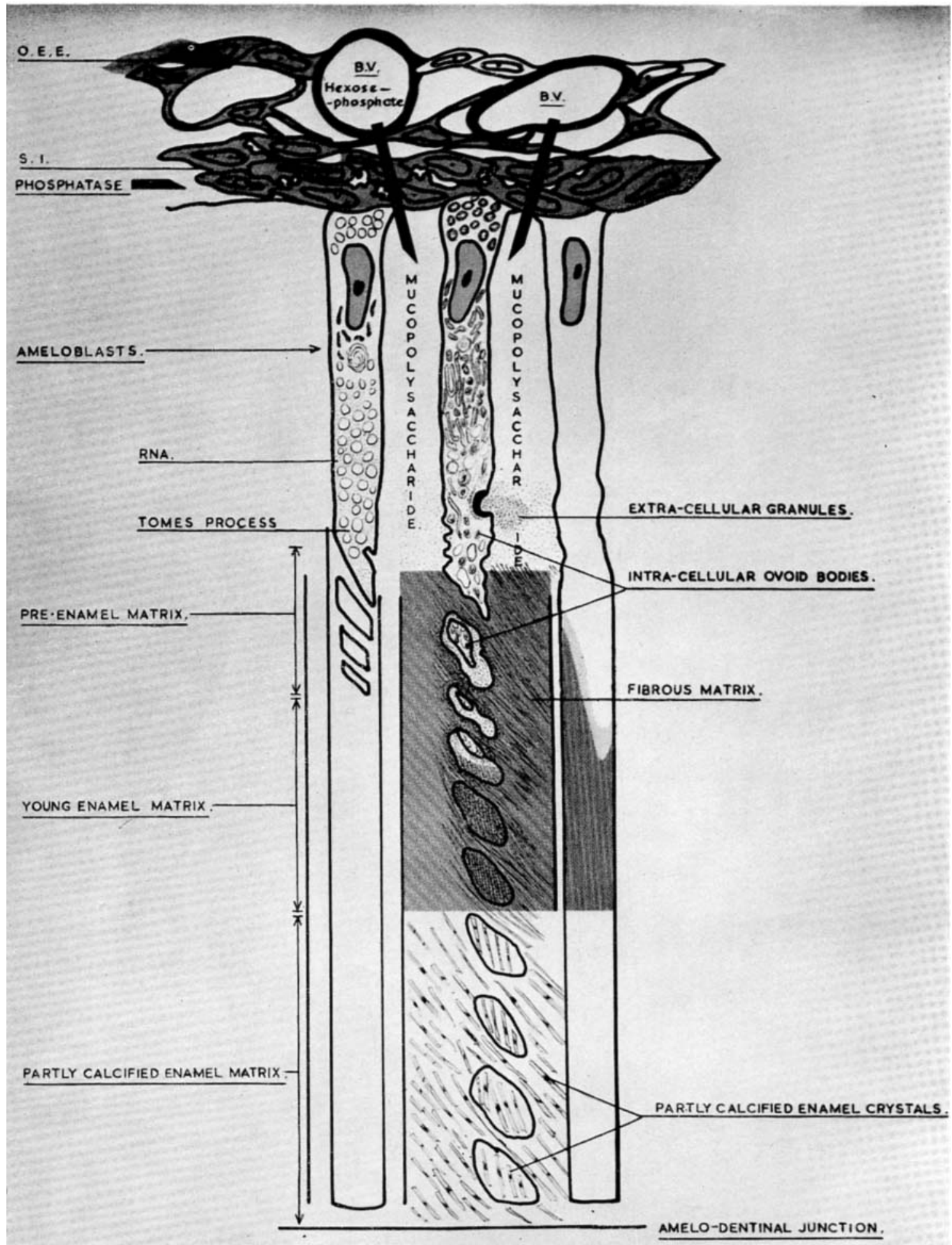

Proceedings of The Nutrition Society, Vol. I8, No. I 
matrix originates from granular material which is elaborated within the ameloblast, or at a special region of the cell wall, and then passes out through the cell wall in the terminal bar region (PI. 2). The Tomes process also contains a precursor of a fibrillar component, but of a different nature, consisting of large oval bodies rather than of a granular material. Definitive inter-rod fibres appear abruptly in the enamel matrix, suggesting a process of orientation. The sudden appearance of 'tape-like' fibres pervading the entire enamel matrix which possess an electron-diffraction pattern characteristic of apatite has also been shown to occur in the fully formed matrix.

The application of histochemistry and electron microscopy to the study of tooth development has shown that complex metabolic and histophysiological processes occur. Experimental nutritional interference with these processes as a method of research into tooth development has demonstrated the occurrence of histological changes in the dental tissues (Wassermann, I944) but, as yet, the mechanism of these changes is not understood. Histochemical and electron microscopical techniques, in conjunction with experimental nutritional interference, were used by Bernick \& Bavetta (1957) in their investigation of the failure of dentine to calcify in tryptophan deficiency. From their findings they were able to conclude that this failure to calcify was the result of an altered state of the dentine ground substance and to show also that a relationship existed between the organic matrix and calcium deposition. This method of approach emphasizes the way in which experimental alteration of the nutritional environment can throw light on the many problems of structure and development still remaining in dental histology and embryology.

\section{REFERENCES}

Avery, J. K. (1954). \%. dent. Res. 33, 646.

Beams, H. W. \& King, R. L. (1933). Anat. Rec. 57, 29.

Bernick, S. \& Bavetta, L. A. (I957). F. dent. Res. 36, 142.

Bevelander, G. \& Johnson, P. L. (1946). F. dent. Res. 25, $38 \mathrm{I}$.

Bevelander, G. \& Johnson, P. L. (1955). J. dent. Res. 34, 123.

Bourne, G. H. (1943). Quart. F. exp. Physiol. 32, r.

Bourne, G. H. (I944). Lancet, 246, 688 .

Bourne, G. H. (1956). In The Biochemistry and Physiology of Bone, ist ed. Chapter 9. [G. H. Bourne, editor.] New York: Academic Press Inc.

Buck, R. C. (1953). \%. Path. Bact. 66, 1.

Butcher, E. O. (1955). F. dent. Res. 34, 676.

Butler, P. M. (1956). Biol. Rev. 31, 3 o.

Cederberg, I. (195I). Acta anat. 12, 334.

de Renyi, G. S. (1933). Amer. F. Anat. 53, 413.

Fearnhead, R. W. F. (1958). Proc. int. Conf. Electron Microscopy. Iv. Berlin. (In the Press.)

Frieden, E. H. \& Hisaw, F. L. (195I). Endocrinology, 49, 4r9.

Frieden, E. H. \& Hisaw, F. L. (1953). Recent Progr. Hormone Res. 8, 333.

Fulmer, H. M. (1958). Lab. Invest. 7, $4^{8}$.

Glasstone, S. (1958). Brit. dent. F. ro5, 58.

Gomori, G. (1943). Amer. F. Path. 19, I97.

Gould, B. S. \& Gold, N. I. (I95I). Arch. Path. (Lab. Med.) 52, 4I3.

Hampp, E. G., (1940). Anat. Rec. 77, 273.

Jackson, S. F. (1956a). Proc. int. Conf. Electron Microscopy. III. Stockholm, p. 229.

Jackson, S. F. (1956b). Proc. roy. Soc. B, 144, $55^{6}$.

James, W. W. (1955). F. Anat., Lond., 89, 547.

Jeener, R. (1947). Nature, Lond., 159, $57^{8}$. 
Kroon, D. B. (1952). Acta anat. 15, 4 .

Landauer, W. (1954). F. cell. comp. Physiol. 43, 261

Marsland, E. A. (1951). Brit. dent. F. 91, 251.

Marsland, E. A. (1952). Brit. dent. F. 92, rog.

Meyer, K. (1947). Physiol. Rev. 27, 335 .

Meyer, K. (1950). Transactions of the First Conference on Connective Tissues, p. 88. New York: Josiah Macy Jr. Foundation

Moog, F. \& Wenger, E. L. (1952). Amer. F. Anat. 90, 339.

Orban, B. (1949). Oral Histology and Embryology, znd ed. London: Henry Kimpton.

Orban, B., Sicher, H. \& Weinmann, J. P. (r943). F. Amer. Coll. Dent. ro, I3.

Porter, K. R. (195I). Transactions of the Second Conference on Connective Tissues, p. 126. New York: Josiah Macy Jr. Foundation.

Robison, R. (I923). Biochem. F, 17, 286.

Sasso, M. D. \& Castro, N. M. (1957). Oral Surg. 10, 1323.

Saunders, J. B. de C. M., Nuckolls, J. \& Frisbie, H. E. (1942). F. Amer. Coll. Dent. 9, 107.

Symons, N. B. B. (1954). F. Anat., Lond., 88, 238.

Symons, N. B. B. (1956). Brit. dent. F. ror, 255 .

Ten Cate, A. R. (1957a). F. dent. Res., 36, 805.

Ten Cate, A. R. (1957b). F. Anat., Lond., 91, 609.

Ten Cate, A. R. (1958). F. dent. Res. 37, 758.

von Brunn, A. (1891). Arch. mikr. Anat. 29, 367 .

Wassermann, F. (1944). F. dent. Res. 23, 463.

Watson, M. L. \& Avery, J. K. (1954). Amer. F. Anat. 95, Iog.

\section{EXPLANATION OF PLATES}

Plate I

Photomicrographs of the human tooth germ.

$a$. At the cap stage of development. The black punctate material is glycogen.

$b$. At the bell stage of development.

c. Undecalcified section illustrating the marked Schiff positivity of the odontoblast cytoplasm during dentinogenesis.

d. Undecalcified section illustrating the distribution of alkaline phosphatase. Note the intense enzyme activity in the stratum intermedium and the subodontoblastic layer. The black precipitate in the dentine and enamel is caused by the presence of calcium salts and should be ignored.

e. Montage photomicrograph of a tooth germ illustrating the disappearance of glycogen from the ameloblasts with the onset of amelogenesis.

a., ameloblasts; d., dentine; d.p., dental papilla; e., enamel; e.o., enamel organ; o., odontoblasts; p.d., pre-dentine; s., subodontoblastic layer; s.i., stratum intermedium; t., Tomes process.

Plate 2

Amelogenesis. Diagram based on results of investigation by electron microscopy of enamel-matrix formation in rodents (after Fearnhead, 1958).

O.E.E., external enamel epithelium; B.V., blood vessel; S.I., stratum intermedium; R.N.A., ribonucleic acid.

\section{The structure of the human tooth}

\section{By A. I. Darling, University of Bristol Dental School}

The human tooth consists largely of dentine. In the centre of the dentine is a cavity which contains the soft tissue of the dental pulp. The dentine is covered on the outer surface of the root by a thin layer of cementum and the dentine of the crown is covered by a layer of enamel. The tooth is slung in its socket by the fibres of the periodontal membrane which stretch from the bone of the alveolus to the cementum. 